\title{
D. The Nature of the Training Stress
}

\section{CHEMORECEPTOR SENSITIVITY RELATED TO ATHLETIC PERFORMANCE}

\author{
A. S. REBUCK, M.B., B.S., M.R.A.C.P. \\ Lecturer in Medicine, University of Sydney, Honorary Assistant Physician, Royal North Shore Hospital, Sydney, Australia
} ABSTRACT

During the study of control of ventilation, the sensitivity of the central chemoreceptor is assessed by measurement of ventilatory response to increasing $\mathrm{CO}_{2}$ tension. We have used a rebreathing technique to measure ventilatory response to $\mathrm{CO}_{2}$ during recovery from asthma (Clinical Science, 1971). It was found that in patients with asthma, ventilatory response to $\mathrm{CO}_{2}$ was impaired, but increased during recovery. Furthermore some patients, who on clinical and spirometric grounds had recovered from their asthma, remained poorly responsive to $\mathrm{CO}_{2}$. In the majority of cases, this was a pointer to underlying lung disease, but in one example no explanation could be found for failure to increase response. This led to the study of a further group of subjects, certain to be free from lung disease, yet with a wide range of physical abilities:- champion athletes.

A remarkably low response, unlike any previously described for normal subjects, was found in two of the long-distance athletes, the pattern being similar to that seen during an attack of asthma $(0.57$ and 0.69 litres $/ \mathrm{min} / \mathrm{mm}$ $\mathrm{Hg}$ ). On the other hand one of the sprinters had a ventilatory response to $\mathrm{CO}_{2}$ over 10 times more sensitive than the long-distance runner, his ventilation increasing by 5.61 litres $/ \mathrm{min} / \mathrm{mm} \mathrm{Hg}$, the second highest response so far reported. This is well outside two standard deviations for a group of $\mathbf{3 8}$ non-athletic normal subjects studied in our laboratory ( mean $=2.68$ litres $/ \mathrm{min} / \mathrm{mm} \mathrm{Hg}$; S.D. = 1.04).

Eight of the athletes held Australian or State records or titles. Amongst these, the ventilation at $\mathrm{PcO}_{2}$ levels of 55 and $65 \mathrm{~mm} \mathrm{Hg}$ was significantly lower for the long-distance runners than for the sprinters.

In order to explore the effect of training, the study was repeated in 5 Australian Olympic Swimmers at a time when they had completed several months endurance swimming. Despite the uniform training programme, a similar pattern to that of the athletes emerged. Two long-distance champions had slopes of $\mathrm{VE}_{\mathrm{E}} / \mathrm{PcO}_{2}$ below $2.0 \mathrm{litres} / \mathrm{min} / \mathrm{mm} \mathrm{Hg}$, while a slope of 8.2 litres $/ \mathrm{min} / \mathrm{mm} \mathrm{Hg}$ was produced by a Mexico Olympic Games sprint medallist, by far the highest level yet reported.

Thus a very wide range of responsiveness of the respiratory centre to $\mathrm{CO}_{2}$ has been demonstrated. It is suggested that the innate sensitivity of the respiratory centre to chemical stimuli may be a major determinant of whether a man can be a champion distance performer.

\section{Introduction}

Control of ventilation is largely a function of the sensitivity of the central respiratory receptors in the medulla. The main stimulus to this centre is carbon dioxide, and response can be measured as minute ventilation. To test the sensitivity of the central receptors, the ventilatory response to increasing $\mathrm{CO}_{2}$ tension can be used, and such testing has revealed some remarkable findings in champion athletes.

We have used a rebreathing technique to measure ventilatory response to $\mathrm{CO}_{2}$ during recovery from asthma ${ }^{1}$. It was found that in patients with asthma, ventilatory response to $\mathrm{CO}_{2}$ was impaired, but increased during recovery. Furthermore, some patients who, on clinical and spirometric grounds had recovered from their asthma, remained poorly responsive to $\mathrm{CO}_{2}$. In the majority of cases this was a pointer to underlying lung disease, but in one example no explanation could be found for failure to increase response. This led to the study of a further group of subjects, certain to be free from lung disease, yet with a wide range of physical abilities.

\section{Methods}

Twelve male athletes, aged from 16 to 25 years were studied. After forced expiratory volume in one second $\left(F E V_{1}\right)$ and vital capacity (VC) had been recorded, ventilatory response to $\mathrm{CO}_{2}$ was measured during 4 minutes of rebreathing from a 6 litre bag, initially containing $7 \% \mathrm{CO}_{2}$ and $50 \%$ oxygen (Read, 1967) ${ }^{2}$. All studies were carried out after the subjects had been sitting quietly for 10 minutes. They had undertaken no athletic performance on the day of the test. The athletes were divided into sprinters and long-distance runners on the basis of athletic performance. 
Results

\section{TABLE I}

\section{ATHLETES}

Vital Capacity, FEV 1 and Ventilatory response to $\mathrm{CO}_{2}$

$\begin{array}{cllll}\text { Subject } & \begin{array}{l}\text { Type of } \\ \text { Athlete }\end{array} & \mathrm{FEV}_{1}(\mathrm{~L}) & \mathrm{VC}(\mathrm{L}) & \mathrm{V}_{\mathrm{E}} / \mathrm{PcO}_{2} \\ * 1 . & \mathrm{L} & 3.35 & & \\ * 2 . & \mathrm{L} & 2.90 & 3.55 & 0.57 \\ 3 . & \mathrm{L} & 4.30 & 3.85 & 0.69 \\ * 4 . & \mathrm{L} & 4.50 & 4.80 & 1.74 \\ * 5 . & \mathrm{L} & 4.70 & 4.50 & 1.78 \\ * 6 . & \mathrm{M} & 3.40 & 5.05 & 3.05 \\ 7 . & \mathrm{S} & 4.70 & 4.15 & 2.89 \\ * 8 . & \mathrm{S} & 4.50 & 4.95 & 1.12 \\ * \text { * } & \mathrm{S} & 3.60 & 5.05 & 1.70 \\ 10 . & \mathrm{S} & 4.00 & 4.05 & 1.71 \\ { }^{*} 11 . & \mathrm{S} & 3.70 & 4.00 & 2.17 \\ { }^{* 12 .} & \mathrm{S} & 4.60 & 4.55 & 3.55 \\ & & & 5.05 & 5.61\end{array}$

$L=$ long distance $\quad M=$ middle distance

$\mathrm{S}=$ sprinter * = 'champion' standard

Details of type of athlete, $F E V_{1}, V C$ and ventilatory response to $\mathrm{CO}_{2}$ are shown in Table 1. Slope of ventilatory response to increasing $\mathrm{CO}_{2}$ (expressed as $\Delta$ $\left.V_{E} / \triangle \mathrm{PcO}_{2}\right)$ has been calculated by the least squares

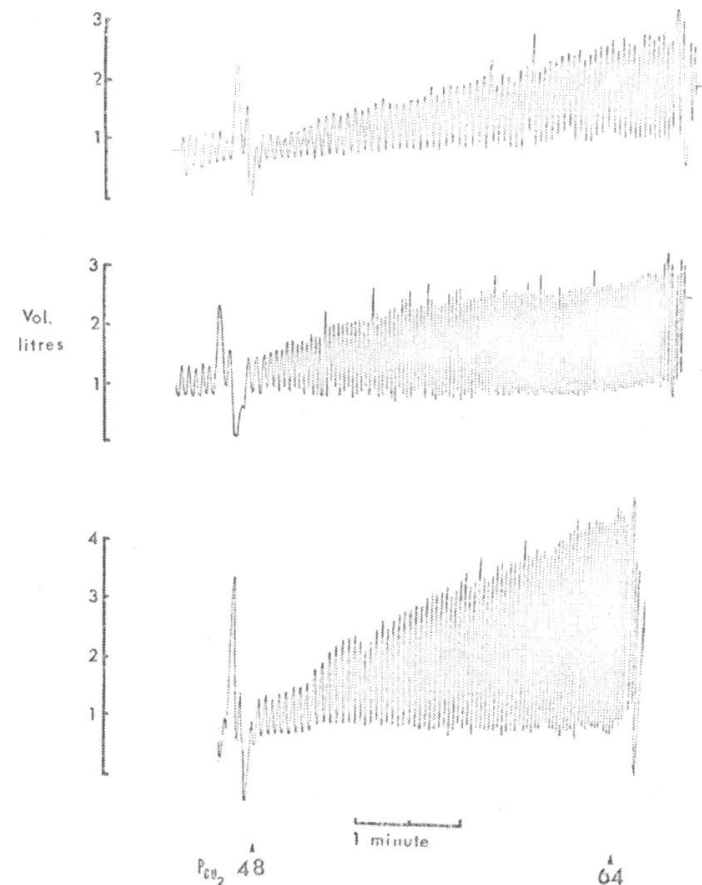

Figure 1. Spirometer records of ventilatory response to increasing $\mathrm{CO}_{2}$ for 3 subjects. regression method. Figure 1 shows the spirometer recordings obtained over the test period for 3 subjects; $\mathrm{PCO}_{2}$ is shown along the lower edge, and tidal volume can be judged from the scale on the left. A wide range of ventilatory response to $\mathrm{CO}_{2}$ can be seen in these records, and this is further illustrated in Figure 2 where regressions of representative $\mathrm{CO}_{2}$ response lines are shown; the upper one is that of a sprinter (S) and the lower line that of a long-distance athlete (L).

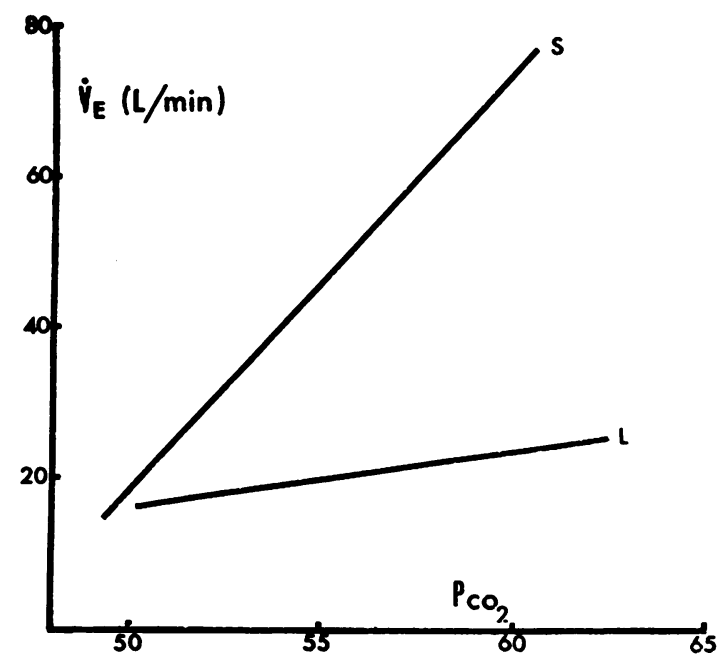

Figure 2. Regression lines of $\bar{V}_{E} / P \mathrm{CO}_{2}$ for a sprinter (S) and a long-distance athlete (L).

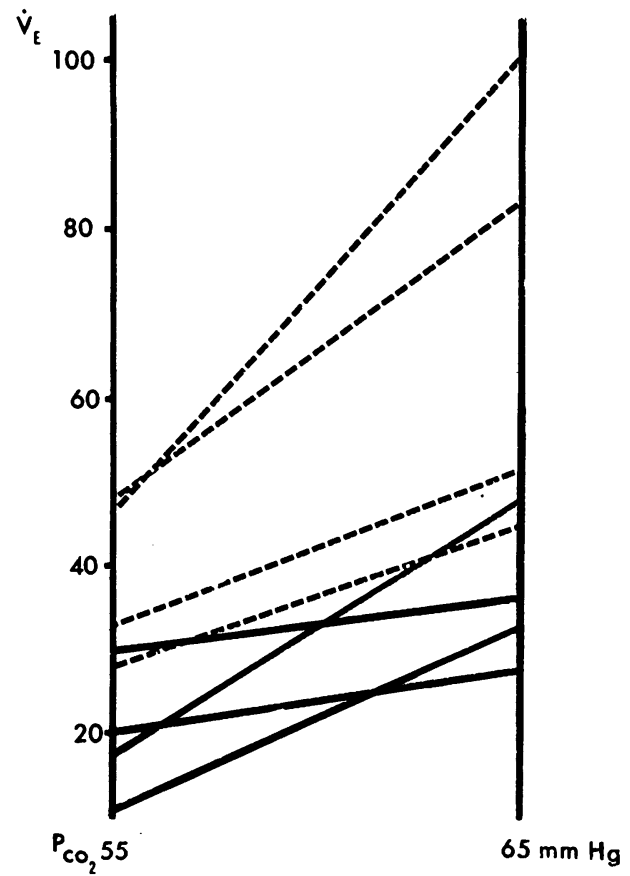

Figure 3. Ventilation $\left(\dot{V}_{E}\right)$ in litres per minute plotted against $\mathrm{PCO}_{2}\left(\mathrm{~mm} \mathrm{Hg}\right.$ ) for 8 champion athletes between $\mathrm{PCO}_{2}$ of 55 and $65 \mathrm{~mm} \mathrm{Hg}$. The uninterrupted lines refer to the long-distance runners, the interrupted lines to the sprinters. 
Two subjects had slopes of ventilatory response to $\mathrm{CO}_{2}$ of 0.57 and 0.69 litres $/ \mathrm{min} / \mathrm{mm} \mathrm{Hg}$ respectively. These are well below any previously described for normal subjects. These subjects are current holders of Australian national records for long-distance events.

The value of 5.61 litres $/ \mathrm{min} / \mathrm{mm} \mathrm{Hg}$ in subject 12 , a current State sprint and hurdles champion, is well outside two standard deviations above the mean for a further 38 normal subjects studied in this laboratory ( mean $=2.68$ litres $/ \mathrm{min} / \mathrm{mm} \mathrm{Hg}$. S.D. $=1.04)$.

Nine of the athletes were current holders of State or Australian records or titles. Figure 3 shows part of the ventilation - $\mathrm{PcO}_{2}$ plot for each of the champion sprinters (dotted lines) and long-distance champions (solid lines) between $\mathrm{PcO}_{2} 55$ and $65 \mathrm{~mm} \mathrm{Hg}$. The levels of ventilation at a $\mathrm{PcO}_{2}$ of both 55 and $65 \mathrm{~mm} \mathrm{Hg}$ were lower for the long-distance performers than for the sprinters $(P<0.025$ and $<0.05$ respectively).

\section{Ventilatory Response to $\mathrm{CO}_{2}$ in Olympic Swimmers}

A major question to be answered is that of the effect of training on the low ventilatory response to $\mathrm{CO}_{2}$ in long-distance champions. Certainly the type of training for long-distance runners is very different from that of sprinters. The study was therefore repeated in five Australian Olympic swimmers. They were selected at a time when they had undergone training under close supervision, swimming between 5 and 9 miles every day for several months:- endurance work by any standards.

\section{TABLE //}

\section{SWIMMERS}

Vital Capacity, FEV 1 and Ventilatory response to $\mathrm{CO}_{2}$

$\begin{array}{llccccc}\text { Subject } & \text { Sex } & \text { Age } & \begin{array}{l}\text { Type of } \\ \text { Swimmer }\end{array} & \text { FEV } & \text { VC } & \dot{V}_{E} / P^{2} c_{2} \\ 1 & M & 15 & M & 4.20 & 4.35 & 2.47 \\ 2 & \text { F } & 15 & \text { L } & 3.40 & 3.65 & 1.75 \\ 3 & M & 21 & \text { L } & 5.05 & 5.15 & 1.50 \\ 4 & M & 18 & \text { S } & 4.20 & 6.00 & 4.86 \\ 5 & M & 21 & \text { S } & 5.95 & 7.30 & 8.17\end{array}$

$L=$ long distance $\quad S=$ sprinter $\quad M=$ middle distance
Results are given in Table II. Despite the uniform training programme, a similar pattern to that in the athletes emerged. Two of the long-distance champions, including the current Olympic 1,500 metres bronze medallist, had slopes of $\mathrm{V}_{\mathrm{E}} / \mathrm{PcO}_{2}$ below 2 litres $/ \mathrm{min} / \mathrm{mm}$ $\mathrm{Hg}$. Two of the sprinters had slopes greater than 4.5 litres $/ \mathrm{min} / \mathrm{mm} \mathrm{Hg}$. The slopes of 8.2 , by far the highest ever recorded, was produced by a Mexico Olympic Games sprint medallist, and is one which if extrapolated would mean that at a $\mathrm{PcO}_{2}$ of $65 \mathrm{~mm} \mathrm{Hg}$ he would be breathing at a rate of $184 \mathrm{I} / \mathrm{min}$.

\section{Discussion}

There have been numerous studies to determine whether parameters of respiratory physiology could account for outstanding athletic performance. Linderholm ${ }^{3}$ has suggested that diffusing capacity of the lungs is a limiting factor for physical working capacity, and it is known that champion middle-distance athletes ${ }^{4}$ and swimmers ${ }^{5}$ have higher diffusing capacities than normal subjects.

No studies have pinpointed any significant difference in pulmonary physiology between sprinters and long-distance champions, although Goff and Bartlett ${ }^{6}$ have noted high end-tidal $\mathrm{PCO}_{2}$ tensions in trained underwater swimmers.

The present study indicates that the combination of slope and position of $\mathrm{CO}_{2}$ response lines can separate subjects with outstanding sprinting ability from those with natural ability for endurance events.

It may be that in athletes the extremes of responsiveness are determined by extremes in the variety of training. However, amongst the swimmers, response correlated more with ability than training. On the other hand, the innate sensitivity of the respiratory centre to chemcial stimuli may be a major determinant of whether a man can be a champion distance performer.

\section{Acknowledgements}

I wish to thank the Australian athletic coach Mr. J. Pross and swimming coach Mr. D. Talbot for their enthusiastic cooperation.

It was the generosity of Dunlop Australia Ltd. which made this presentation possible.

\section{REFERENCES}

1. REBUCK, A. S., and READ, J.: 'Ventilatory response to $\mathrm{CO}_{2}$ during recovery from asthma.' Clin. Sci. 41, 13 , 1971.

2. READ, D. J. C.: 'Clinical method for assessing ventilatory response to carbon dioxide.' Australas. Ann. Med. 16, $29,1967$. 
3. LINDERHOLM, H.: 'Diffusing capacity of the lungs as a limiting factor for physical working capacity.' Acta. Med. Scand. 163, 61, 1959.

4. BANNISTER, R. G., COTES, J. E., JONES, R. S. and MEADE, F.: 'Pulmonary diffusing capacity in athletes and non-athletic subjects.' J. Physiol., London. 152, 66, 1960.

5. MOSTYN, E. M., HELLE, S., GEE, J. B. L., BENTIVOGLIO, L. G. and BATES, D. V.: 'Pulmonary diffusing capacity of athletes.' J. Appl. Physiol. 18, 687, 1963.

6. GOFF, L. G. and BARTLETT, R. G.: 'Elevated end-tidal $\mathrm{CO}_{2}$ in trained underwater swimmers.' J. Appl. Physiol. 10, 203, 1957.

\title{
THE NATURE OF THE TRAINING STIMULUS: EFFECTS OF INTENSITY, FREQUENCY AND DURATION OF EXERCISE ON MAXIMUM AEROBIC POWER
}

\author{
C. T. M. DAVIES ${ }^{1}$ and A. V. KNIBBS ${ }^{2}$ \\ ${ }^{1}$ M. R. C. Environmental Physiology Unit, London School of Hygiene \& Tropical Medicine, \\ ${ }^{2}$ London and City of Leeds \& Carnegie College of Education, Leeds
}

\begin{abstract}
The major physiological responses of man to training have now been well established (see Åstrand 1956 for general review) but surprisingly few data are available on the exact and most efficient way the changes which accompany repeated exercise are elicited.

We have attempted to extend the work of Shephard (1968) by studying the effects of various regimens of exercise varying in intensity, duration and frequency of effort on maximum aerobic power $\left(\dot{\mathrm{V}} \mathrm{O}_{2}\right.$ max $) .28$ healthy male subjects aged 19-38 years were studied over an 8-week period during work on a stationary (Müller) bicycle ergometer. Each subject was carefully habituated to work (see Davies, Tuxworth \& Young 1970) and then required to exercise at $80 \%$ or $50 \%$ or $30 \%$ of his $\mathrm{VO}_{2} \max$ for 5 or 10 or $20 \mathrm{~min}$; once, three or five per week. Their responses to submaximal and maximal work were measured directly immediately before and following the period of training.

Analysis of the results showed that the two most important factors in training the $\dot{\mathrm{V}} \mathrm{O}_{2}$ max were intensity and duration, these parameters being interdependent. Indeed, no subject who exercised below $50 \%$ of his $\dot{\mathrm{V}} \mathrm{O}_{2}$ max showed an improvement in maximum aerobic power (cf. Durnin, Brockway and Whitcher 1960). Even at the highest intensities and longest durations of effort the improvement of $\mathrm{V}_{2}$ max was quite small and ranged from $9 \mathrm{mls} / \mathrm{kg} / \mathrm{min}$ to 4 $\mathrm{mls} / \mathrm{kg} / \mathrm{min}$. The responses to submaximal work mirrored in part these changes: cardiac frequency at oxygen intake of $1.5 \mathrm{~L} / \mathrm{min}\left(\mathrm{f}_{\mathrm{H}} 1.5\right)$ decreased whereas $\dot{\mathrm{V}}_{2}$ at a given workload and $\dot{\mathrm{V}}_{\mathrm{E}} 1.5$ remained constant before and after training.

Thus from the results it would appear that in order to effect a change in maximum aerobic power a person must be prepared to work for a period of time at or close to his $\mathrm{V}_{2}$ max; even then the increase may be disappointingly small.
\end{abstract}

\section{REFERENCES}

1. ÅstRAND, P. O. (1956) Physiol. Rev. 36, 307-335.

2. DAVIES, C. T. M., TUXWORTH, W. T. and YOUNG, J. M. (1970) Clin. Sci. 39: 247-258.

3. DURNIN, J. V. G. A., BROCKWAY, J. M. and WHITCHER, H. W. (1960). J. Appl. Physiol. 15, 161-165.

4. SHEPHARD, R. J. (1966) J. Canad. Med. Ass. 96, p.899. 
THE INFLUENCE OF PEDALLING RATE AND WORK INTENSITY ON VISUAL RESPONSE TIME AND SOME RESPIRATORY AND CIRCULATORY VARIABLES DURING ERGOMETRIC WORK

\author{
I. SZMODIS, M.D. and J. MALOMSOKI. Eng.Chem. \\ Research Dept., National Institute of Sports Medicine, Budapest, Hungary.
}

\begin{abstract}
Serially measured simple visual response time (SVRT) was previously found to increase early and proportionately to the load during exercise. This increase was assumed to be related also to extraneural factors.

In order to discriminate between the effects of work load and pedalling rate a $4 \times 4$ Latin square experimental design was used, and the respective effects of the two stimuli were investigated at two levels. In addition to SVRT several respiratory and circulatory variables were concomitantly observed (respiratory and pulse rate, tidal volume, respiratory gas exchange, excess $\mathrm{O}_{2}$ consumption per work unit, ventilation and maximal oxygen pulse).
\end{abstract}

Intensity change was confirmed to be a potent factor, but as regards SVRT the effect of rate change was negligible. On the other hand, rate change exerted significant influence on respiratory rate, tidal volume, respiratory gas exchange and pulse rate. In some variables the respective effects of rate change and intensity change were not simply additive, though in general both stimuli made the variables rise.

\section{Introduction}

In several human activities the rate at which work is done has an importance of its own. It is a factor in ergometry statements about which always accompany the description of exercise.

The purpose of this study was to separate as far as possible the respective effects of work load and pedalling rate in a bicycle ergometric exercise. The hypothesis to be tested was whether the frequency of pedal revolutions might be expressed simply as an additional amount of work or else it exerted specific effects.

\section{Methods and Material}

To this end, 50 and 100 watt loads were combined with 50 and 100 revolutions of pedalling per minute and the combinations were arranged in a Latin square design. Four male subjects aged $15,19,32$ and 38 , performed altogether 32 exercise tests on four consecutive days. Sessions took place in the morning and in the afternoon, and the design required that the combinations be performed by another subject each time. After completing the scheme the design was repeated in a different assignment.

The tests consisted of three periods: pre-exercise rest, 6 minutes; work, 6 minutes; and recovery 10 minutes. ECG pulse rate, respiratory gas exchange and arhythmical serial simple visual response time were measured throughout each test. This time only work period data will be dealt with.

Except oxygen pulse and oxygen cost the values of the ten physiological variables were averaged for the last 3 minutes of work. The design was evaluated by analysis of variance and F-test and the variability associated with other than the two main factors under study could be separated. The level of significance was set at $5 \%$.

Results

Though a 50 watt increase in work load is moderate, it elicited a greater effect in respiratory rate and tidal volume (Fig. 1.) than the increase in pedalling rate. 50 or $100 \mathrm{rpm}$ may be considered a substantial difference, since feasible pedalling rates cover a considerably smaller range numerically than do work loads expressed in watts.

The increases observed in pulmonary ventilation, oxygen consumption and $\mathrm{CO}_{2}$ production (Fig. 2.) were all significant in respect of both factors. Work load was found to be a more potent factor again.

Similarly, the respective differences of mean respiratory quotient, pulse rate and peak oxygen pulse attained during steady-state work (Fig. 3.) were significant too.

Mean visual response time and the amount of excess $\mathrm{O}_{2}$ consumed per unit of work (Fig. 4.) behaved in a manner unlike the other variables. In response time the increased work load elicited some elongation in agreement with our previous report. On the other hand, that part of the elongation which was attributable to the effect of the higher rate of pedalling, was surprisingly slight and was found to be statistically non-significant. 


\section{$\square 50$ 田100 $\bar{f}_{R} \pm 1,0$}

W

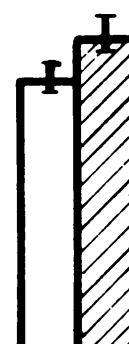

$18,922,2$
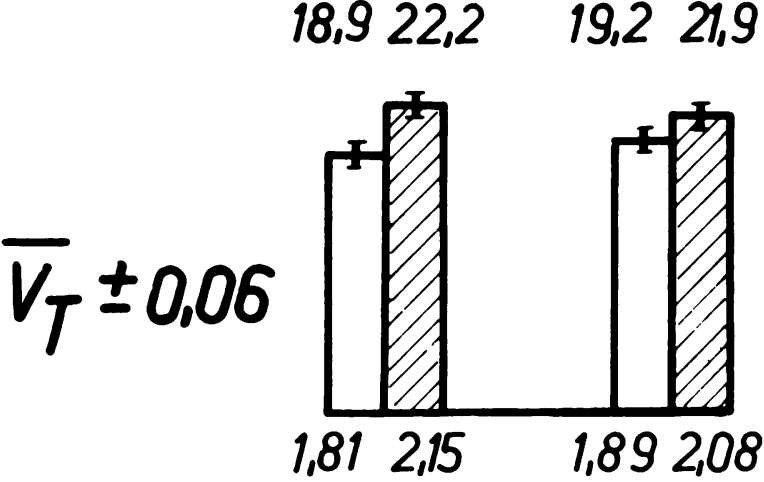

Fig. 1. Respiratory rate and tidal volume at two levels of work load and pedalling rate. - In this and following figures $W$ denotes effect of work load, and rpm that of pedalling rate. 50 and 100 levels of both factors are indicated by the same shading. Variability in the bars and after the symbols of variables represents standard error of the mean. Numerical value of the means are shown below the bars. $-f_{R}$ : mean respiratory rate. $\bar{v}_{T}$ : mean tidal volume/litre.

The relationship of total excess oxygen consumption per unit of work is an expression of the oxygen cost, i.e. inverse of the economy of work. It was found to be less in heavier work, a sign of better economy. At the higher rate of pedalling however this quotient was significantly greater and indicated that oxygen intake rose more steeply than work did under the less favourable conditions.

\section{Discussion}

Several authors have emphasised that the most economic rate of pedalling is at about $\mathbf{5 0} \mathrm{rpm}$ (Müller, Hendrik, etc.). Eckermann and Millahn found a parabolical relationship between oxygen intake, pulse rate and pedalling frequency. Higher than optimum frequency apparently represented additional and less economic work.

Some of the present results, however, favour an interpretation that would allow for other effects.

Oxygen cost was found by Malomsoki to show relative improvement with higher loads. This was confirmed also this time. Higher pedalling rate elicited however a contrary effect which was as great or slightly greater than the former.

Response time, too, was shown previously to grow with increasing severity of exercise, and in regard of the work load alone it was evidenced again. The higher rate of pedalling failed however to change visual response time.

It may be concluded therefore that the rate of pedalling ought not to be understood as being simply an
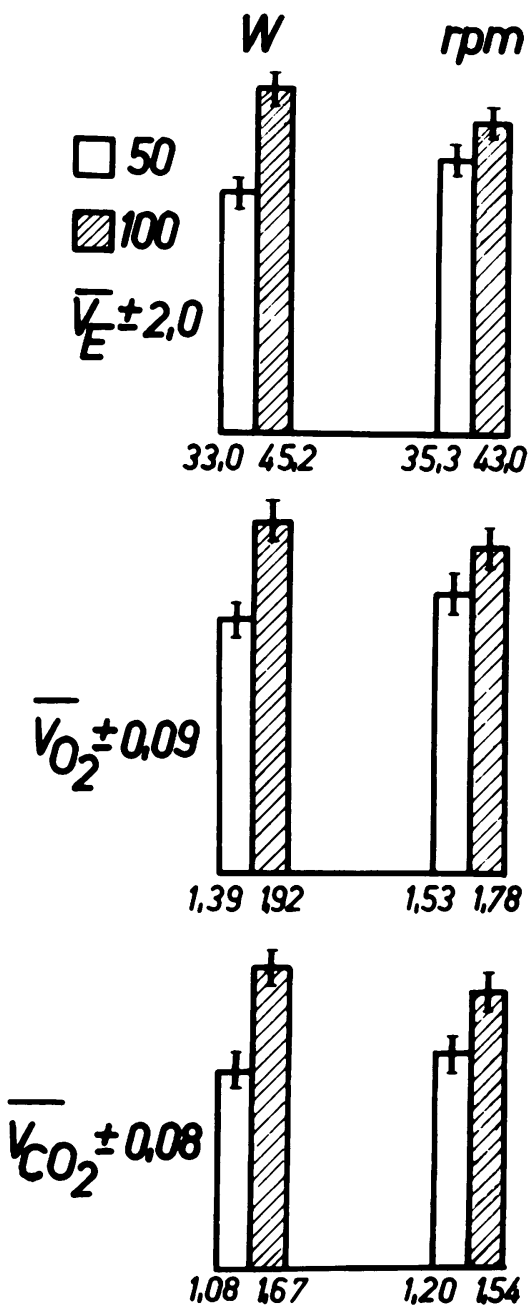

Fig. 2 Pulmonary ventilation, $\mathrm{O}_{2}$ intake and $\mathrm{CO}_{2}$ production at two levels of work load and pedalling rate. $\bar{V}_{E}$ : mean minute volume of expired air. $\bar{V}_{O_{2}}$ : mean minute volume of $\mathrm{O}_{2}$ intake. $\overline{\mathrm{CO}}_{2}$ : mean minute volume of $\mathrm{CO}_{2}$ production/litres/. Other notation as before. 
additional amount of work load, but possesses also some specific effects which in some functions may counteract those elicited by work intensity alone. In connexion with the relative insensitiveness of response time to
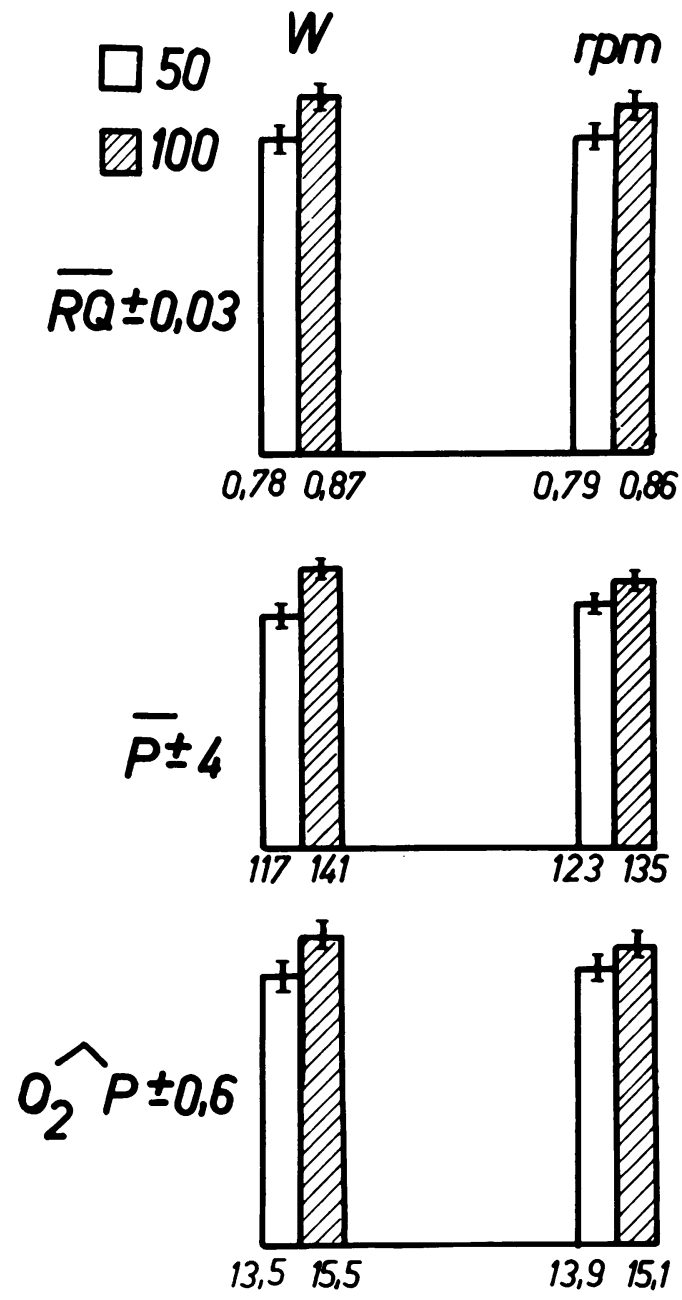

Fig. 3. Respiratory quotient, pulse rate and oxygen pulse at two rates of work load and pedalling rate. $\overline{R Q}$ : mean steady-state respiratory quotient. $\bar{f}_{P}$ : pulse rate. $\mathrm{O}_{2} / \mathrm{P}$ : peak steady-state oxygen pulse. Other notation as before. higher rates of movements further research seems warranted as well as in respect of the higher oxygen cost. Both these aspects are of interest for sports physiology and practical training alike.

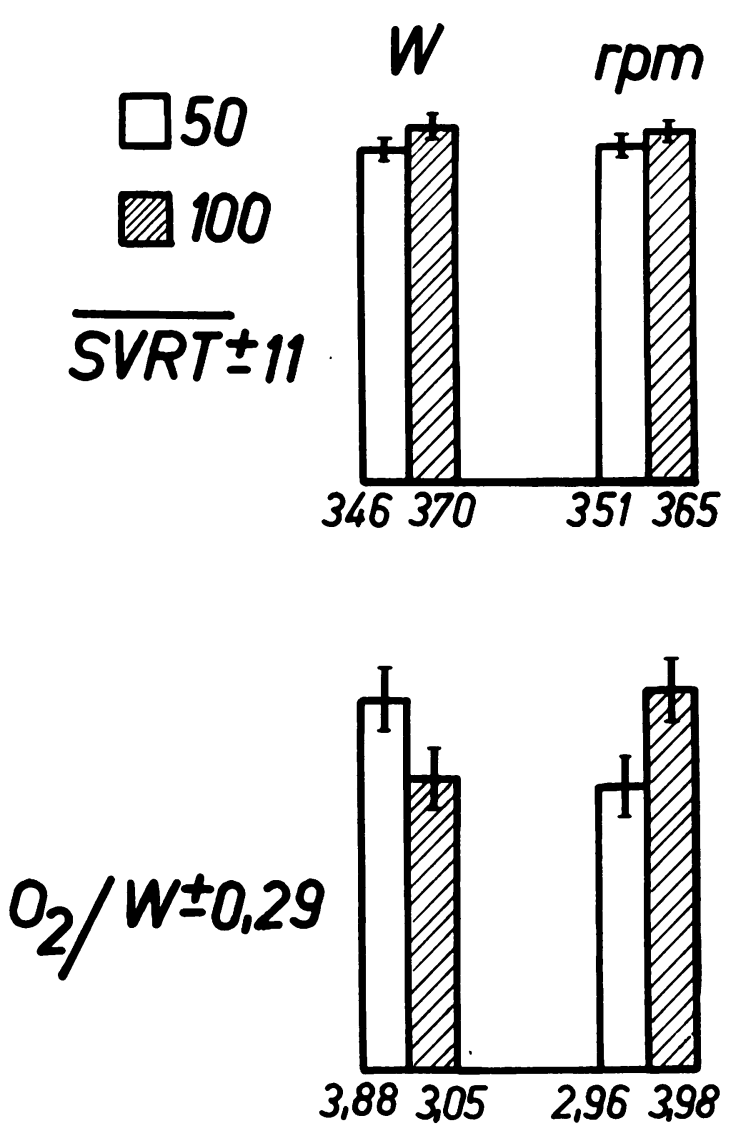

Fig. 4. Visual response time and oxygen cost at two levels of work load and pedalling rate.

SVRT: mean serial simple visual response time in msec. $\mathrm{O}_{2} \mathrm{~W}$ : excess $\mathrm{O}_{2}$ intake per unit of work in $\mathrm{ml} / \mathrm{kpm}$. Other notation as before.

\section{REFERENCES}

1. ECKERMANN, P., and H. P. MILLAHN: Der Einfluss der Tretfrequenz auf die Sauerstoffaufnahme und die Herzfrequenz bei konstanter Leistung am Fahrradergometer. pp. 131-136 in: Methoden und Probleme der angewandte und Leistungsphysiologie. VEB Verlag Volk und Gesundheit, Berlin, 1967.

2. GROSSE-LORDEMANN, H., and E. A. MÜLLER: Das Einfluss der Leistung und der Arbeitsgeschwindigkeit auf das Arbeitsmaximum und den Wirkungsgrad beim Radfahren. Arbeitsphysiologie 9: 454, 1937. 
3. HENDRIK, A.: Untersuchungen zur optimalen ergometrischen Belastung. Z. inn. Med. 19: 690-693, 1964.

4. MALOMSOKI, J.: A növekvö terhelés szerepe a gázanyagcsere vizsgálatokban. Effects of increasing loads in respiratory|gas exchange studies, (Hung*) Testnev. Sporteu. Szle. 5: 109-114, 1964.

5. MALOMSOKI, J., M. NEMESSÚRI, I. SZMODIS, M. SZÁSZ: AZ erokifejtés és a reakcióido közti kapcsolat. Connexions between physical effort and response time, (Hung*) Testnev. Sporteu. Szle. 10: 13-18, 1969.

* Hung = article written in the Hungarian language.

\title{
PERCEPTION OF EFFORT DURING DIFFERENT TYPES OF EXERCISE AND UNDER DIFFERENT ENVIRONMENTAL CONDITIONS
}

\author{
J. S. SKINNER, R. HUTSLER, V. BERGSTEINOVA \& E. R. BUSKIRK \\ Laboratory for Human Performance Research, The Pennsylvania State University, \\ 103 Human Performance Building, University Park, Pa. 16802.
}

\begin{abstract}
Man's perception of work can be affected by physical conditioning, body fatness, health status, and the work environment. To further clarify the concept of perceived exertion, several experiments were conducted. Eight lean and eight obese men were given random workloads on a bicylce ergometer to determine how the values obtained compared with those during progressively increasing workloads. Insignificant differences were found. These subjects were then progressively exercised to maximum on a bicycle ergometer, where body weight was supported and on a treadmill, where their weight was transported. The treadmill test was given at normal temperatures $(23-250 \mathrm{C})$ and at warm temperatures $\left(31-33^{\circ} \mathrm{C}\right)$. Subsequently, the lean subjects wore vests weighted to equate their excess weight with that of the obese subjects. Oxygen consumption, ventilation, respiratory frequency, heart rate (HR), and a rating of perceived exertion (RPE) were recorded. With identical workloads, obese subjects had lower HR and RPE on the bicycle and higher values on the treadmill. The warm environment raised the HR and RPE but not oxygen consumption. With the different types of exercise and environments the same RPE was associated with the same HR, but not necessarily with the absolute amount of work done or the metabolic requirements of that work.
\end{abstract}




\title{
REVIEW OF PHYSIOLOGICAL AND MENTAL STATE VARIABLES THAT PREDICT ABILITY AT BICYCLE TIME TRIAL RACING
}

\author{
' J. D. BROOKE, Ph.D., ${ }^{2}$ E. J. HAMLEY, Ph.D., ${ }^{2}$ P. T. STONE, B.Sc. \\ ${ }^{1}$ Human Performance Laboratory, University of Salford, Lancs. and \\ ${ }^{2}$ Department of Ergonomics \& Cybernetics, University of Technology, Loughborough, Leics.
}

\begin{abstract}
Performance on a laboratory cycle ergometer work task to exhaustion for racing cyclists correlated highly with road racing ability. To determine predictors of this ability within the group physiological responses for the maintenance of adequate oxygen potential and indices of performers' mental states were studied. The curve functions for changes in fractional diffusion of oxygen at the lung $\left(F_{1}-F_{E O_{2}}\right)$ against increasing work very significantly correlated with maximum work ability $(R=+0.93)$. Efficiency of tissue respiration, control of circulation and control of ventilation are indicated. Heart rate curvilinearity was also a highly significant correlate with the maximum work. $\dot{V}_{E \max }, V_{02 m a x}$ and fHmax were not.
\end{abstract}

The predictive mental state variables are accounted for by the neurophysiological theory of selective attention. Shifts in thresholds for low level sensory stimuli as metabolic disequilibrium developed correlated significantly with work ability and with blood $\left[\mathrm{cH}^{+}\right]$|at exhaustion. Laboratory pain and personality questionnaire measures were non-predictive. Factor analysis of all measures reached interaction between selective attention variables and ventilation at exhaustion.

Human biology theory guided the supported hypotheses about the metabolic and mental states. The significant determinants of work ability now direct sensitive study of rates and levels of adaptation with training practices.

\section{Introduction}

The work done when an athlete competes is partly the result of aerobic and partly the result of anaerobic metabolism. In aerobiosis the adequate oxygen potential at the exercising muscle is the product of a metabolic chain frequently studied by measurement of the lung gas exchange, the blood gas transport and the heart activity as a circulatory pump. In work that is primarily aerobic, unit increases in work elicit unit increases in the responses of the mechanisms in this metabolic chain.

This equilibrium characterises homeostasis. Eventually limits to these responses are reached, immediate accounting for further increases in work is through anaerobic processes which draw on finite reservoirs of energy in a closed system and metabolic Disequilibrium results. Frequently this disequilibrium is specific to a link in the chain and there is some opportunity to compensate when limits are approached: for example consider the increases in cardiac output that occur by increases in heart rate versus increases in stroke volume. It may be appropriate therefore to use the term disequilibrium by reference to the site of the disturbance.

Mental awareness of the sensory stimuli identifying disturbed metabolic conditions also allows some flexibility in the athlete's determination of a limit. The reports of individual variability in the degree of metabolic disequilibrium at incapacity ${ }^{1}$ suggests that there are individual differences in such awareness of the distress or pain of exhausting exercise. To study such differences in tolerence we have preferred to use the theory of selective attention developed from neurophysiological work by Hagbarth ${ }^{2}$, Granit \& $\mathrm{Kaada}^{3}$ and Hernandez-Peon ${ }^{4}$. This research, mainly on animals but with some clinical studies, reported maintained neural discharge in the sensory tract commanding behavioural attention with reduced transmission of the impulses in the remainder of the recorded afferent flow. Pain stimuli have been found to interact with the awareness of other sensory stimulation $5 \%$ and it may be hypothesised that the unpleasant sensations associated with the metabolic disequilibrium of exhausting physical work may be related to changes in the sensitivity in other sensory channels. This we have studied by psycho-physical tests of sensory thresholds in subjects performing physical work tasks in the laboratory. For the same work tasks measures of the metabolic responses of oxygen uptake, oxygen fraction, ventilatory volume and heart rate have been obtained. Following a preliminary study ${ }^{7}$, statistics from these metabolic and mental variables have been directed to solving the research problem of how to predict the road racing ability of time-trial cyclists.

In the main experiments twenty male time-trial racing cyclists, each performed after practice, six trials of a laboratory cycle ergometer task of physical power 
output increasing continuously and linearly at a rate of 30 watts $/ \mathrm{min}$ from 60 watts initial load up to exhaustion. The final level of power output at exhaustion was termed the maximum work ability. The mean value was 428 watts, SD 43 watts. Exhaustion was defined as the inability to continue voluntarily to maintain the required pedal rate of 90 revolutions per minute. As the intention was to relate the laboratory procedure to the racing ability these maximum work abilities were correlated with rank ordered road racing ability derived by three experienced judges. The

TABLE 1 DESCRI PTIVE STATISTICS AND TRIAL BY TRIAL RELIABILITY COEFFICIENTS FOR THE PFYSIOLOGICAL AND WORK MEASURES significant Spearman rho correlation of 0.84 indicates the validity of the laboratory work. The trial by trial reliability coefficients shown in Table 1 demonstrate that there was adequate replicability of the experimental procedures.

Fig. 1 shows a typical graph of the responses in the physiological variables over the work task. From these curves statistics were obtained for (a) the linear rate of change of responses achieving balance with the work load, (b) the negative quadratic curvature that occurs when further responses are inadequate but the work load continues to increase and (c) the maximum value for each of the variables. (For the ventilatory volume the negative quadratic was not calculated for it only occurred in two cases.) Fig. 2 illustrates this type of analysis applied to the heart rate 899 . The three statistics $a, b$ and $c$, were obtained by orthogonal polynomial curve fiting with significance testing of the fit by least squares regression analysis.

These statistics were used to predict the work ability $10 / 11$. With $\hat{y}$ as the dependent variable of work ability and $x_{i}$ as the $n$ independent predictor variables of the

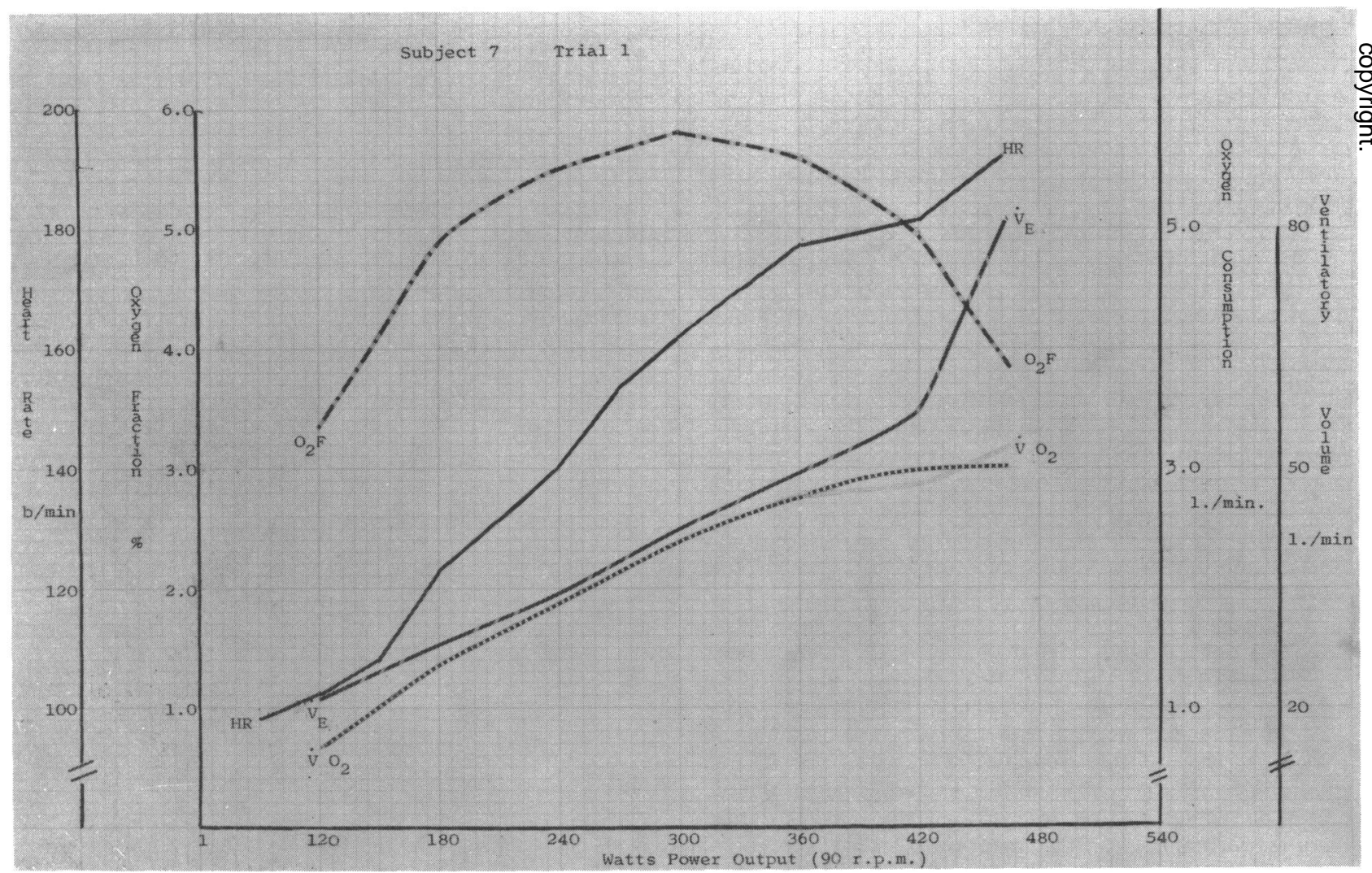

Fig. 1 Common patterns of physiological response to a load of work continuously increasing to exhaustion. 


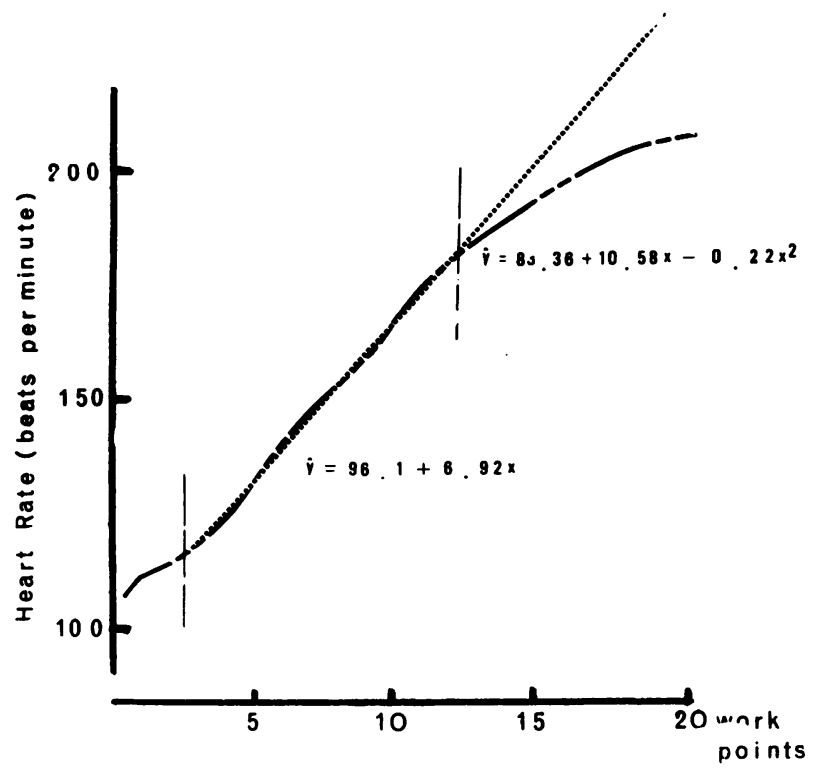

Fig. 2 Heart-rate curve analysis for one subject

various physiological responses, equations of the form

$$
\hat{y}=a+b_{1} x_{1}+b_{2} x_{2}+b_{3} x_{3} \ldots \ldots b_{n} x_{n}
$$

were calculated by multiple regression analysis.

All eleven predictive statistics used together and correlated with work ability gave $R=0.99$, a very high correlation. By gradual removal of the least predictive statistics this was eventually reduced to the two best predictors, as shown in Table 2. The statement

$$
\underset{\text { (watts) }}{\dot{y}}=157.9+65.3 F_{1}-F_{E 0_{2}} \text { max. }+1134.4 F_{1}-F_{E 0_{2}}{ }^{2}
$$

accounted for $80 \%$ of the variance in work ability, a highly significant correlation of 0.89 . It is noteworthy that the $V_{E \max }, V_{0_{2}} \max$ and $H R_{\max }$ were not significantly related to the work ability in this situation. Neither was the maximum uptake of oxygen per $\mathrm{kg}$ body weight. Yet the mean $H R_{\max }$ of 193, SD 9.00 and mean $\left[\mathrm{CH}^{+}\right]$at exhaustion of 6.34 , SD 0.76 suggest that high levels of work were achieved. It is proposed that the high correlation with the work ability of the maximum fraction of oxygen extracted is most probably attributable to the efficiency of the respiration at the exercising muscles or to the control of circulation to this site leading to a lower mixed venous oxygen partial pressure.

At two levels in the work two psycho-physical tests were conducted and during these four trials the subjects

\begin{tabular}{|c|c|c|}
\hline Predictor Variable: & $\begin{array}{l}\text { Multiple Correlation } \\
\text { Coefficients with W }\end{array}$ & $\begin{array}{l}\text { \% of Varia } \\
\text { W accounte }\end{array}$ \\
\hline all ll & 0.99 & 97 \\
\hline $\begin{array}{l}\mathrm{O}_{2} \mathrm{~F}^{\mathrm{m}}, \dot{\mathrm{V}}_{\mathrm{E}} \mathrm{O}_{2}^{\mathrm{m}}, \mathrm{HR}^{\mathrm{m}}, \\
\mathrm{HR}^{2}\end{array}$ & 0.98 & 96 \\
\hline $\begin{array}{c}5-\dot{v}_{E}^{1}, o_{2} F^{2}, o_{2} F^{1} \\
o_{2} F^{m}, \dot{v}_{E} O_{2}{ }^{m}\end{array}$ & 0.98 & 95 \\
\hline $\begin{array}{c}4-\mathrm{O}_{2} F^{2}, o_{2} F^{m}, o_{2} F^{1} \\
\dot{v}_{E}^{1}\end{array}$ & 0.97 & 95 \\
\hline $3-\mathrm{O}_{2} \mathrm{~F}^{\mathrm{m}}, \mathrm{O}_{2} \mathrm{~F}^{2}, \mathrm{O}_{2} \mathrm{~F}^{1}$ & 0.93 & 87 \\
\hline $2-0, F^{m}, O_{2} F^{2}$ & 0.89 & 80 \\
\hline
\end{tabular}
were not encumbered with physiological equipment.
Changes between the work levels in the initial hearing threshold (HT) to a $4000 \mathrm{c} / \mathrm{s}$ tone were studied in the 3rd and 5th trials to exhaustion and changes in the just-noticeable-difference (JND) for pressure on the tibia in the 4th and 6th trials. Trials took place on separate days. The work levels for stimulus presentations were $30 \%$ and $97 \%$ of each subject's total work range, representing respectively states of metabolic homeostasis and severe disequilibrium.

In the JND test compressed air through a sphygmomanometer cuff resting distally against the medial malleolus projection gradually pressed a $5 \mathrm{~mm}$ long metal projection against an approximately $50 \mathrm{~mm}^{2}$ skin contact area on the anterior surface of the tibia. The time from the start of the air flow at $1.7 \mathrm{I} . / \mathrm{min}$ to the subject's awareness of the pressure change was the JND.

Testing the initial sound threshold a standard audiometer (Kamplex TA15) and ear-phones were used with a canvas web helmet and chin straps assisting the spring head band to maintain stability. The tone increasing in amplitude every other presentation was transmitted from initially below threshold to the subject for one second every three seconds at the appropriate times. The first amplitude of the tone perceived was the HT.

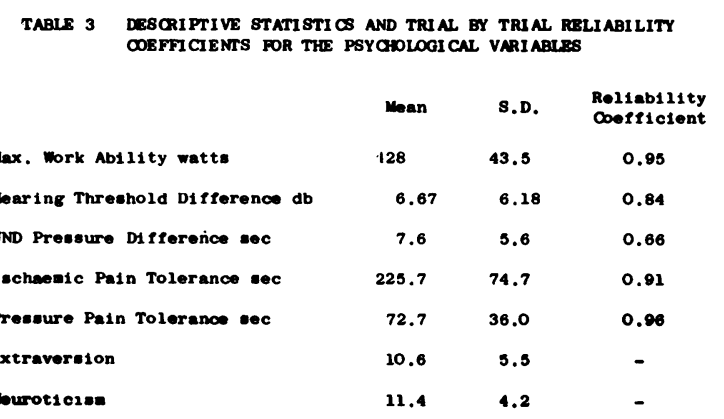




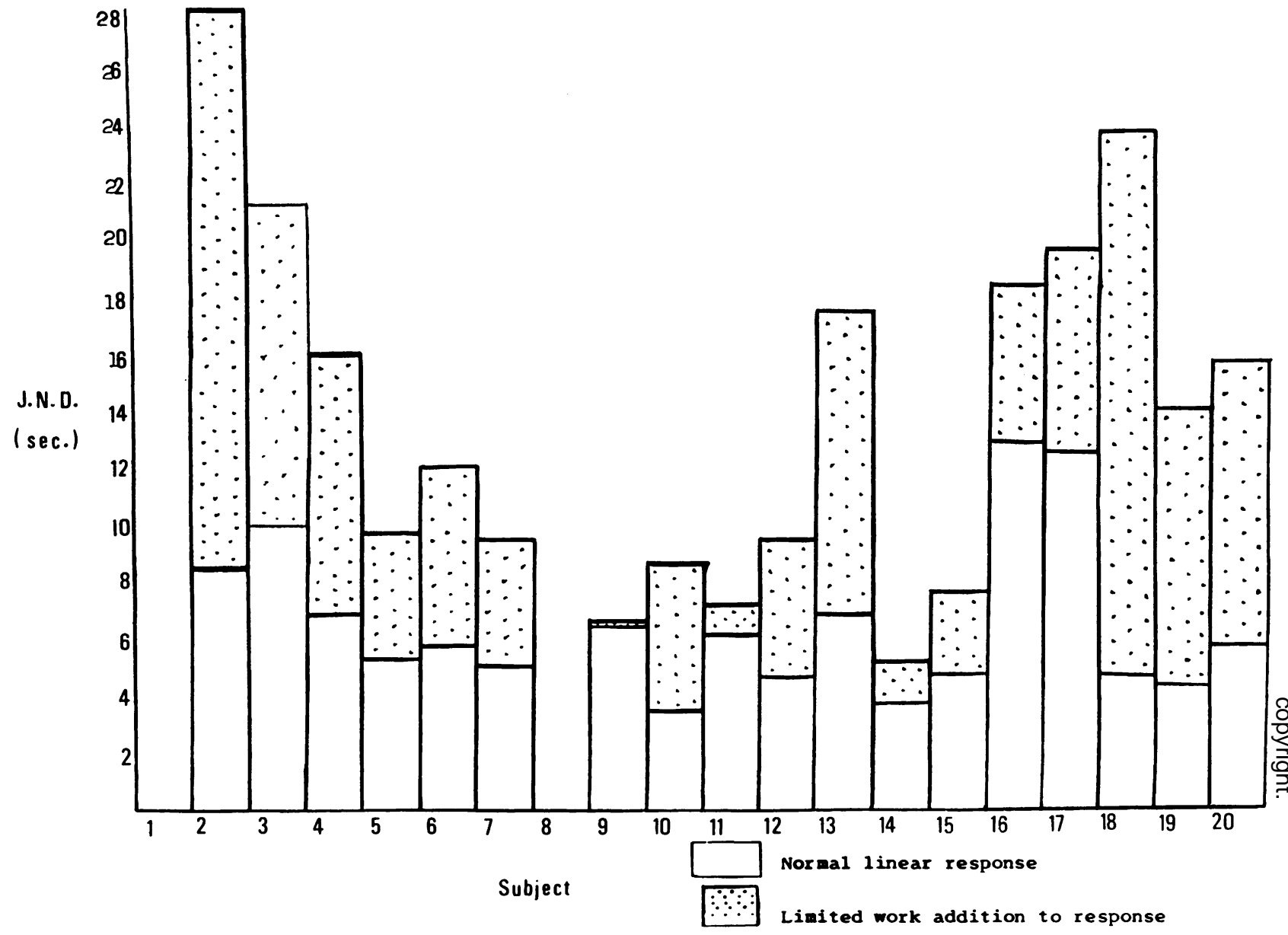

Fig. 3 J.N.D. pressure changes in the normal linear and limited work state

In each psycho-physical test six training stimulus presentations were made during the preparatory work. After training, subjects were told not to concentrate on the stimulator but to respond if a signal was perceived. Table 3 shows the reliability coefficients for the measures.

Figs 3 and 4 show the highly significant increases that occurred in both sensory thresholds during fatigue. Fig. 4 also shows the influence of the ergometer noise, for the sound threshold values taken at the first work level are well above the zero decibel standard threshold. The shifts in sensory threshold were not merely time effects for in two subjects riding the same period of time but with no load increase that might lead to exhaustion there was no meaningful change.

The degree of threshold shift in JND in pressure correlates highly significantly with the maximum work ability. Table 4 shows the inter-correlations. The change (d) in JND most correlated with the work ability, accounting for $36 \%$ of the variance in the latter. The combined regression of dJND and dHT raises this to predict $50 \%$ of the work variance, a highly significant relationship.

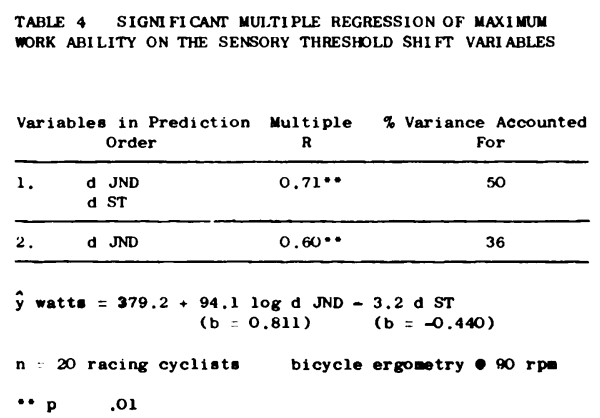




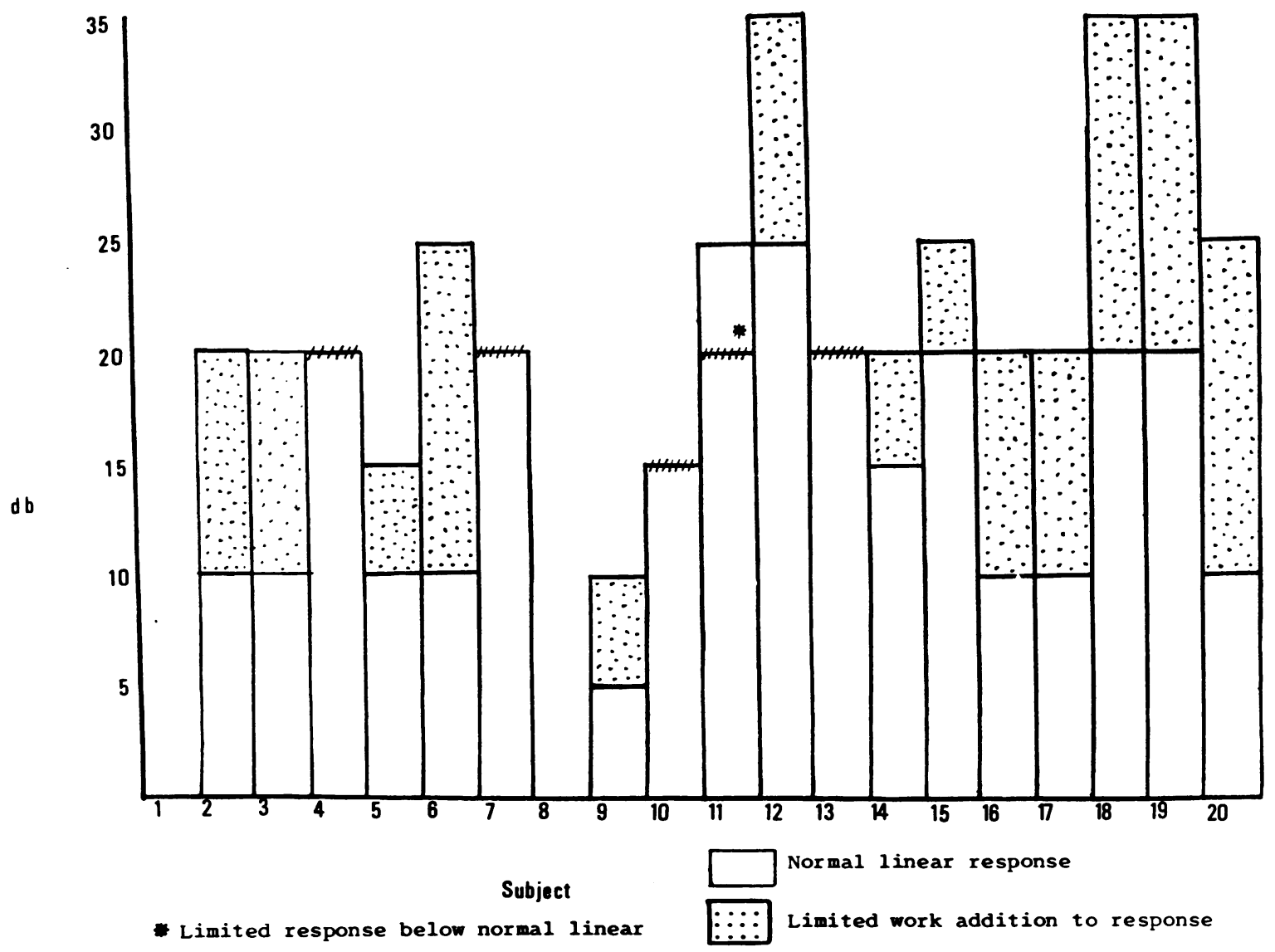

Fig. 4 Initial sound thresholds for each subject in the normal linear and the limited work states

In addition to this common variance between the work tolerance and the mental state, the level of the $\left[\mathrm{CH}^{+}\right]$of the whole blood at exhaustion also related significantly to dJND $(r=0.5)$ and to work ability $(r=0.5)$. Borg ${ }^{12}$ found that the perceived intensity of pain from physical work was significantly related to the level of the blood lactate and thus tc a changed acid-base state and our results show similar interaction between the increase in the active hydrogen ion concentration of the blood, the magnitude of the changes in the mental state that might be hypothesised from such increasing pain intensity and the level of the work ability.

In attempts to extend this application of the theory of selective attention, laboratory pain tolerance levels and Eysenck's personality continuum of extraversion have been tested as predictors of the work ability.

Tolerance to the ischaemic pain of controlled work of the flexor digitorum (D3) of an occluded arm, as described earlier ${ }^{13}$, and the upper threshold for pressure pain using the pressure plate procedure for the JND in pressure test but allowing the pressure to rise to intolerance with the subject off the ergometer were measured. The trial by trial reliability coefficients were 0.91 and 0.96 respectively. Scores for extraversion and neuroticism were obtained for responses to Form $A$ of the Eysenck personality questionnaire ${ }^{14}$. While there was a significant correlation between the two pain measures there were no significant simple correlations between the measures of pain tolerance or personality and the work ability. This supported earlier research on the competitive sports ability of male ${ }^{15}$ and female ${ }^{16}$ physical education students where similar non-significant results were obtained although we have often found such sportsmen to be significantly extraverted as a group $15 / 16 / 7$. When added to the multivariate predictive equations for the variables of the mental state little was contributed.

All the measures of the metabolic condition and the mental state on all subjects were submitted to multivariate analysis. The intention was to (a) predict the work ability and (b) describe how the measures 


\begin{tabular}{|c|c|c|c|c|c|c|}
\hline & $\begin{array}{l}\text { Work Ability through effic- } \\
\text { lent oxygen provision and } \\
\text { resistance to limitation } \\
\text { I }\end{array}$ & $\begin{array}{l}\text { Physical pressure } \\
\text { tolerance } \\
\text { II } \\
\end{array}$ & $\begin{array}{c}\text { Oxygen supply despite } \\
\text { advancing limftations } \\
\text { III }\end{array}$ & $\begin{array}{l}\text { Heart Load } \\
\text { IV }\end{array}$ & $\begin{array}{c}\text { Attention } \\
\text { V }\end{array}$ & \\
\hline$\dot{\mathrm{v}}_{\mathrm{E}}{ }^{\mathrm{l}}$ & 0.820 & -0.279 & 0.365 & 0.089 & 0.099 & $v_{E}^{1}$ \\
\hline$\dot{\mathrm{v}}_{\mathrm{E}}^{m}$ & 0.163 & -0.841 & -0.189 & -0.049 & 0.342 & $\dot{\mathrm{v}}_{\mathrm{E}}^{\mathrm{m}}$ \\
\hline $\mathrm{O}_{2} \mathrm{~F}^{1}$ & -0.683 & 0.157 & 0.151 & -0.447 & -0.222 & $\mathrm{O}_{2} \mathrm{~F}^{1}$ \\
\hline $\mathrm{O}_{2} \mathrm{~F}^{2}$ & -0.337 & -0.238 & -0.739 & -0.018 & 0.388 & $\mathrm{O}_{2} \mathrm{~F}^{2}$ \\
\hline $\mathrm{O}_{2} \mathrm{~F}^{\mathrm{m}}$ & -0.660 & -0.252 & 0.076 & -0.490 & -0.063 & $\mathrm{O}_{2} \mathrm{~F}^{\mathrm{m}}$ \\
\hline$\dot{\mathrm{V}}_{\mathrm{E}} \mathrm{O}_{2}{ }^{1}$ & 0.520 & -0.306 & 0.755 & 0.022 & 0.109 & $\dot{\mathrm{v}}_{\mathrm{E}} \mathrm{O}_{2}{ }^{\mathrm{l}}$ \\
\hline$\dot{\mathrm{V}}_{\mathrm{E}} \mathrm{O}_{2}^{2}$ & 0.054 & -0.139 & -0.830 & 0.049 & -0.051 & $\dot{\mathrm{V}}_{\mathrm{E}} \mathrm{O}_{2}^{2}$ \\
\hline$\dot{\mathrm{V}}_{\mathrm{E}} \mathrm{O}_{2}^{\mathrm{m}}$ & -0.105 & -0.600 & 0.154 & -0.590 & 0.180 & $\dot{\mathrm{V}}_{\mathrm{E}} \mathrm{O}^{\mathrm{m}}$ \\
\hline $\mathrm{HR}^{1}$ & 0.358 & 0.504 & 0.440 & 0.333 & 0.221 & $\mathrm{HR}^{1}$ \\
\hline$H \mathbb{R}^{2}$ & -0.860 & -0.300 & -0.217 & 0.147 & -0.082 & $\mathrm{HR}^{2}$ \\
\hline $\begin{array}{l}\mathrm{HR}^{\mathrm{m}} \\
\mathrm{CH} \\
\triangle \mathrm{ST} \\
\mathrm{LOB} \triangle \mathrm{JND} \\
\mathrm{PT} \\
\text { log IT } \\
\text { Extraversion } \\
\text { Ne'irni:cisn } \\
\text { Work }\end{array}$ & $\begin{array}{r}0.014 \\
-0.148 \\
0.137 \\
-0.458 \\
-0.093 \\
-0.561 \\
0.330 \\
-0.098 \\
-0.822 \\
\end{array}$ & $\begin{array}{r}-0.192 \\
-0.089 \\
-0.135 \\
0.081 \\
-0.844 \\
-0.469 \\
-0.045 \\
-0.008 \\
-0.095\end{array}$ & $\begin{array}{r}\frac{-0.354}{-0.238} \\
0.087 \\
0.090 \\
-0.060 \\
0.064 \\
-0.154 \\
-0.089 \\
-0.347 \\
\end{array}$ & $\begin{array}{r}\frac{0.624}{-0.633} \\
0.001 \\
-0.405 \\
0.129 \\
0.417 \\
0.171 \\
-0.493 \\
-0.411\end{array}$ & $\begin{array}{r}0.047 \\
0.427 \\
0.920 \\
0.659 \\
-0.076 \\
0.369 \\
0.542 \\
-0.059 \\
0.106\end{array}$ & $\begin{array}{l}\mathrm{HR}^{\mathrm{m}} \\
\mathrm{CH} \\
\Delta \mathrm{ST} \\
\log \Delta \mathrm{ND} \\
\mathrm{PT} \\
\log \mathrm{IT} \\
\text { Extr } \\
\text { Neuro } \\
\text { Work }\end{array}$ \\
\hline $\begin{array}{l}\% \text { Trace of } R \text { accounted } \\
\text { for by each root } \\
\text { Accumulated\% }\end{array}$ & $\begin{array}{l}22.289 \\
22.289\end{array}$ & $\begin{array}{l}14.530 \\
36.819\end{array}$ & $\begin{array}{l}13.810 \\
50.629\end{array}$ & $\begin{array}{l}13.263 \\
63.892\end{array}$ & $\begin{array}{l}12.431 \\
76.323\end{array}$ & \\
\hline
\end{tabular}

psycho-physical measures and lower loadings for extraversion (0.542), $\left[\mathrm{CH}^{+}\right]$(0.427), maximum ventilatory volume $(0.342)$ and the negative quadratic coefficient for the oxygen fraction extracted (0.388).

Most interaction of the mental and metabolic measures occurred between the selective attention variables and the ventilation as the work approached exhaustion. An important site for the filtering of the sensory flow to the cortex is reported to be via collaterals from the main sensory pathways to the ascending reticular activating system of the brain stem, mid-brain and thalamus. The central control trigger involved in Melzack \& Wall ${ }^{18}$ neural gate control theory of pain may be located similarly.

With the amount of central nervous control of ventilation demonstrated in the reticular formation of the medulla, the anatomical proximity of these centres suggests that this interaction might be anticipated. However it is not clear whether (a) the neural activity involved in activating the ventilatory reponse causes modifications to the filtering of the afferent flow or (b) the reverse takes place, that is the neural activity in the reticular activating system causes modifications in the control centre for ventilation or (c) whether the changing metabolic state is causing changes in the $\left[\mathrm{CH}^{+}\right]$ of the blood and of the cerebro-spinal fluid by $\mathrm{CO}_{2}$ diffusion, so that in both the ventilatory centres and the activating centres the disturbed homeostasis is altering the neural discharge in the manner that Dell has described $^{19}$.

However, these are problems arising from our results.

\section{Conclusion}

1. The metabolic variables allowed high prediction of the maximum work ability. For these time-trial racing cyclists the fractional extraction of oxygen was most predictive.

2. Changes in the mental variables of the perception of sensory thresholds related significantly to the maximum work ability. The extraversion and neuroticism personality measures and measures of laboratory pain were not predictive of this work performance.

3. There was some interaction between the mental variable of selective attention to sensory thresholds and the metabolic variables for the lung ventilation at exhaustion. 


\section{REFERENCES}

1. ÅSTRAND, P. O. (1952) Experimental studies of working capacity in relation to sex and age. Copenhagen, Munkegoord

2. HAGBARTH, K. E. (1960) Centrifugal mechanisms of sensory control. Ergeb. Biol., 22, 47-66

3. GRANIT, R. \& KAADA, B. R. (1953) Influence of stimulation of central nervous structures on muscle spindles in cats. Acta Physiol. Scand. 27, 130

4. HERNANDEZ-PEON, R. (1966) Physiological mechanisms in attention. In: Russell, R. W. (Ed) Frontiers in Physiological Psychology. New York, Academic Press, p121-147

5. BENJAMIN, F. B. (1955) Interaction of pain and other sensations. Amer. J. Med. Sci. 230, 226

6. BENJAMIN, F. B. (1955-56) Effect of pain on simultaneous perception of non-painful sensory information. $J$. Appl. Physiol. 8, 630-4

7. ARCHER, J., HAMLEY, E. J. \& ROBSON, H. E. (1965) The fitness assessment of competitive cyclists. Physical Education, 57, July.

8. BROOKE, J. D., HAMLEY, E. J. \& THOMASON, H. (1968) The relationship of heart-rate to physical work. J. Physiol. 197, 61-63P

9. BROOKE, J. D., HAMLEY, E. J. \& THOMASON, H (1968) Normal and strain heart-rate responses to work load increasing continuously and by steps. J. Physiol. 201, 33-34P

10. BROOKE, J. D., HAMLEY, E. J. \& THOMASON, H. (1968) The regression of cardiac, ventilatory and somatic measures on power output in subjects accustomed to fatigue. Paper to Int. Symposium on 'Stress and Fatigue'. Perm. Com. \& Int. Assoc. for Occu. Health, Paris

11. BROOKE, J. D. (1969) Tolerance to Physical work. Ph.D. Thesis, Loughborough University of Technology.

12. BORG, G. A. V. (1962) Physiological Performance and Perceived Exertion. Sweden, Lund

13. BROOKE, J. D., COOPER, D., HAMLEY, E. J. \& SAVILLE, B. F. (1967) An electromyographical analysis of noxious ischaemic work. BASM Bull. 3, 1, 26

14. EYSENCK, H. J. \& EYSENCK, S. B. G. (1964) The Eysenck Personality Inventory. London, The University

15. BROOKE, J. D. (1967) Extraversion, physical performance and pain perception in physical education students. Res. in PE 1, 2, 23-30

16. BROOKE, J. D., HAMLEY, E. J. \& STONE, P. J. (1969) Personality, achievement in physical competition, physique and grip strength in female physical education students. Med. \& Sci. in Sports. 1, 4, 185-8.

17. STONE, P. T. (1961) Is the athlete different in personality from the non-athlete? Paper to BASM Conference, Loughborough, June 1961.

18. MELZACK, R. \& WALL, P. D. (1968) Gate control theory of pain. In: Soulairac, A., Cahn, J. \& Charpentier, J. (Eds.) Pain. London, Academic Press

19. DELL, P. (1964) Reticular homeostasis and critical re activity. In: Moruzzi, G. et al (Eds.) Progress in Brain Research: Vol. 1. Brain Mechanisms. New York, Elsevier 


\title{
HYPOXIC EXERCISE
}

\author{
R. C. GOODE, D.Phil (Oxon)
}

Department of Physiology, University of Toronto, Toronto, 5, Canada.

\begin{abstract}
It is generally agreed that humoral and neural stimuli are the principal means by which muscular exercise influences respiration.

The experiments of Harrison, Harrison, Calhoun and Marsh (1932); Asmussen, Christensen and Nielsen (1943) and Dejours (1963) provide good evidence for the neural component. A humoral component to the drive to ventilation during exercise has been accepted for some time (Haldane and Priestly, 1905; Asmussen and Nielsen, 1946; Bannister and Cunningham 1954 and Dejours, 1963).
\end{abstract}

Experiments by Dejours and his group have provided evidence for a neural-humoral relationship (Dejours, Raynaud, Cuenod and Labrousse, 1955; Dejours, 1963, 1964). The neural factor in combination with reported chemical changes can account for most, if not all, of the ventilation in euoxic exercise (Cunningham, 1963; Matell, 1963; Cunningham, Spurr and Lloyd, 1968). However in hypoxic exercise the addition of the appropriate neural drive (Dejours, 1963 Cunningham, Spurr and Lloyd, 1968) to a calculated chemical drive results in a level of ventilation that is well below that observed (Cunningham, 1968).

The form of the hypoxic- $\mathrm{CO}_{2}$ response curve (Cunningham, Spurr and Lloyd 1968) might reveal possible mechanisms that could underlie this apparent increase in responsiveness. Asmussen and Nielsen (1957) published two $V_{E}, P_{A}, \mathrm{CO}_{2}$ response curves in hypoxic exercise. The $\mathrm{CO}_{2}$ response curves, though initially steep, demonstrated reduction in slope. As there was substantial scatter of experimental points in these experiments it is difficult to make an accurate estimation of the slope. Preliminary experiments by the author and others (Bhattacharyya, Cunninghams Goode, Howson and Lloyd, 1968) revealed two distinct patterns; a parallel shift and a curving or flattening-out of the: hypoxic- $\mathrm{CO}_{2}$ response line. The cause of the curving or flattening-out is possibly a result of the subject approaching the limit of his ventilatory capacity or that $\mathrm{CO}_{2}$ and hypoxia at high and low concentrations respectively have an inhibitory effect on the respiratory centre (Asmussen and Nielsen, 1957). Indications of increased responsiveness of the subject to the alveolar $\mathrm{CO}_{2}$ pattern in hypoxia might be an alternative explanation (Goode, Brown, Howson and Cunningham, 1969).

\section{PULMONARY PATHO-PHYSIOLOGY OF EXERCISE - HYPOXAEMIC INTERACTION}

$$
\text { J. A. DEMPSEY, Ph.D. }
$$

1300 University Avenue, 7th Center - University Hospitals, Madison, Wisconsin 53706.

\section{ABSTRACT}

Combinations of varying degrees of physical work with self or experimentally induced arterial hypoxaemia present a potent interactive stress in the gas exchange function of the lung. We have studied the synergistic effect of exercise and hypoxia.

The effect of exercise on the ventilatory response to steady state hypoxia in an isocapnic state were studied to try and analyse the drives to hypoxic exercise.

The pulmonary response to exercise was studied in patients with alveolar hypoventilation and $\mathrm{CO}_{2}$ retention.

A comparison was made of exercise and respiratory responses in populations exposed to moderate altitude $(3100 \mathrm{~m})$ both long and short term. 